\title{
Revisiting language teaching materials in a time of change
}

\author{
Revisitando materiais didáticos de línguas em tempos de mudança
}

\author{
Lucilla Lopriore* \\ Roma Tre University \\ Roma, Itália
}

\begin{abstract}
The purpose of this contribution is to elicit a reflective perspective on the role and function of English language teaching materials traditionally used in the language classroom, in a time of change for English and for the pedagogical principles underlying its teaching. This time of change is represented by the emergence of English as a Lingua Franca (ELF), by the growing diffusion and use of information communication technology (ICT), by approaches to language learning inclusive of content (CLIL), and by contexts characterised by plurilingualism and multiculturalism An overview of what traditionally accompanies teachers and learners - from course-books to teachers' self-produced handouts - in the teaching-learning process of a language whose current status is undergoing major changes, is first presented. A reflective approach in the teaching of English within a moveable scenario where new language contacts are challenging English traditional standards and its varieties and the role of language for learning has been informing classroom practice, is then offered and implications discussed. This contribution has deliberately chosen to focus only on a few of the numerous research fields and tools that are emerging in the language classroom and within the teaching materials scenarios, such as the notion of authenticity, the use and role of corpora, the function of communicative and mediation strategies, the representation of culture and the emergence of intercultural competence. Implications and practical suggestions for teaching materials follow each of the sections.
\end{abstract}

Keywords: teaching materials, authenticity, English as a Lingua Franca, language awareness, change

Resumo: O objetivo deste artigo é apresentar uma perspectiva reflexiva sobre o papel e a função dos materiais didáticos de língua inglesa tradicionalmente utilizados na sala de aula de língua, em um momento de mudança para o inglês e para os princípios pedagógicos subjacentes ao seu ensino. Este momento de mudança é representado pelo surgimento do inglês como Língua Franca (ELF), pela crescente difusão e uso da tecnologia de comunicação de informação (TIC), por abordagens de aprendizado de línguas inclusive de conteúdo (CLIL) e por contextos caracterizados por Plurilinguíssimo e multiculturalismo. Uma visão geral do que tradicionalmente acompanha os professores e aprendizes - desde livros de cursos até as apostilas produzidas pelos professores - no processo de ensino-aprendizagem de uma língua cujo status atual está sofrendo grandes mudanças, é apresentado pela primeira vez. Uma abordagem reflexiva no ensino de Inglês em um cenário móvel, onde novos contatos de idiomas estão desafiando o Inglês padrão tradicional e suas variedades e o papel da linguagem para a aprendizagem tem sido pensado na prática de sala de aula, vislumbrando e implicações que merecem ser discutidas. Nesse artigo escolhemos deliberadamente concentrar-nos apenas em alguns dos inúmeros campos de pesquisa e ferramentas emergentes na sala de aula de língua e dentro dos cenários dos materiais de ensino, como a noção de autenticidade, o uso e o papel dos corpora, a função de comunicação e estratégias de mediação, a representação da cultura e o surgimento de competências interculturais. Implicações e sugestões práticas para materiais didáticos seguem cada uma das seções.

Palavras-chave: materiais de ensino, autenticidade, inglês como Lingua Franca, consciência da língua, mudança

* Professora Associada de Linguística e Tradução da Língua Inglesa na Università Roma Tre.

Email: lucilla.lopriore@uniroma3.it. 


\section{LANGUAGE TEACHING MATERIALS}

Materials in the field of foreign or second language teaching have traditionally been associated with all that supports and sustains teachers in their job before, during and after the language lessons as, for example, the course-book that has traditionally been perceived and used by both teachers and learners as the backbone of language learning (SHELDON, 1987; COOK, 2003; LITTLEJOHN, 2011). But course-books do not always provide all that is needed in the language classrooms, and teachers usually look for other forms of support to their work, particularly authentic audio, video or written texts preferably accompanied by appropriate learning tasks. They can thus either resort to publishers or develop their own materials (CANDLIN \& BREEN, 1979; RICHARDS, 1993, 2014; UR, 1996; LITTLEJOHN, 2011; TOMLINSON, 2003).

There are different types of teaching materials differently designed, including teacher-developed materials, commercial materials and technology-driven materials. Traditionally supporting course-books, language teaching materials - paper or digital texts - can be represented by publishers' products or just by teachers' own selected and/or adapted foreign language audio or video input from all types of multimedia texts available in the press as well as on the internet. Language teaching materials are often produced and distributed by publishers, usually the first ones to perceive changes occurring in the field and ready to offer immediate teaching solutions; but materials are also frequently developed by teachers themselves, who add their personal response to their teaching needs as well as their own perspective in the teaching-learning process. So, when practitioners talk about teaching materials, they usually refer to all that would help them enhance the learning environment in their daily work and what they look for is often, but not always, provided by the publishers. When publishers talk about materials, they usually perceive them as a set of teachers' most needed products, often, research-based, to be distributed in the market (LITTLEJOHN \& WINDEATT, 1989; RICHARDS, 1993; RICHARDS \& MAHONEY, 1996; HOWATT \& SMITH, 2014). There is thus some sort of mismatch between what teachers and students actually need, how their needs are being perceived by the publishers and what is then offered on the market. There are also cases where needs are induced and teachers often end up adjusting to new products without questioning their value for learning.

Publishers' products usually consist of course-books, grammar books, on-line learning and teaching resources such as workbooks for learners' home revision, test practice, international certifications exam preparation, pronunciation apps, extra listening files, videos and documentaries, live interviews usually accompanied by supporting tasks, etc . A vast number of research studies and publications have specifically addressed language teaching materials, but the majority of these mainly focus upon criteria to be adopted for material evaluation or guidelines for material design and development (TOMLINSON, 2003, 2010, 2011). Very seldom publications on materials have taken into consideration how materials are being used and perceived by both teachers and learners inside and outside the classroom walls (GARTON \& GRAVES, 2014: 2) and 
how teachers develop their own materials as a response to those societal changes and innovations that may affect education as well as learners' language learning (TOMLINSON, 2012:144). Since teacher-produced materials are localised responses to specific needs, they often play an important role to bridge the gap between the classroom and the world outside and reveal emerging trends in language teaching.

\section{A TIME OF CHANGE}

The last thirty years, characterized by globalization and major societal changes, have in diverse ways influenced language education and determined challenging innovations in English language teaching (ELT), redefining its construct and its approaches. One of the most interesting and visible changes in ELT is teaching English within a moveable scenario where new language contacts are challenging English traditional standards as well as its varieties. The intensive social fragmentation processes due to the recent tidal migration flows, together with the unstoppable diffusion of new technologies, social networks and multimedia, have created new sociolinguistic environments where languages are undergoing a unique transformative process of their borders as well as of their traditional functions.

Among the major changes of the last two decades, the growing diffusion of multilingual population and the changes English has undergone, have both proved extremely influential in language education. English has spread all over the countries in addition to the autochtonous languages, but without actually threatening their existence, rather 'with the advantage of being ethnically neutral' (KNAPP, 2015, p. 174). As David Graddol (2006, p.9) underlined in English Next, his second report on the status of English, the relationship between English and globalisation is a complex and reciprocal process since "economic globalisation encouraged the spread of English but the spread of English also encouraged globalisation". This wide diffusion of English has raised a number of issues regarding its varieties, its function in a global, multicultural and plurilingual society and the implications of teaching it in different contexts all around the world.

A number of research studies on new instantiations of English are beginning to have an impact on language teaching approaches and acquisition theories in multilingual contexts; this has inevitably been influencing the development, choice and use of coursebooks and materials. The shift towards a more learner-centred approach in contexts where the vast majority of English teachers are non-native speakers, demands for changes in materials design, specifically in terms of resources that would constitute the input and of the type of tasks being used. Materials, according to Tomlinson, should "provide exposure to authentic use of English through spoken and written texts with the potential to engage the learners cognitively and affectively" (TOMLINSON, 2010, p. 4), and should "include activities which help learners to notice for themselves salient features of the texts" (TOMLINSON, 2010, p. 5). These recommendations reflect the implications of the changes occurring at educational level as well as those triggered by the sociolinguistic 
scenarios and by the need to revisit English language use.

The new scenarios offered by the multiple language and transcultural flows, by the emergence of English as a Lingua Franca (ELF) and by the role and function of the nonnative English speakers teachers (NNESTs), challenge existing paradigms and demand teachers and publishers for a shift in perspective particularly in terms of English language teaching and material development (SHARIFIAN, 2009; COLEMAN, 2011; GARTON \& GRAVES, 2014). Questions such as "What English or whose English needs to be taught?" are not only investing curricular choices, but they are unveiling features of language education, such as the notion of authenticity, the aural-oral processes or the native standard models, that are all worth revisiting, together with the idea of revaluing the potential of English users' frequent use of code-switching, translanguaging or codemeshing in interactions. All of this constitute a new perspective to be added in teaching as well as in language teaching materials.

\section{CHANGES AND IMPLICATIONS IN LANGUAGE TEACHING MATERIALS}

The previously described societal and sociolinguistic changes currently affecting English language education are of diverse nature: from the widespread use of ICT and of social networks, to the emergence of ELF and of multilingual interactions, where learners - and teachers - are more and more exposed to a globalized context, to out-of-school exposure to English thanks to the daily contact with the Internet, with TV series and from localised materials. Teachers find themselves in a situation where their learners' needs are not as predictable as they had been for a long time, where course-books and materials are only partially a response to those needs. What type of actions are thus likely to be undertaken by publishers, teachers and material developers? Actions that would take into account a moveable scenario where English is a plurilithic reality and learners are already using English to interact with other non-native speakers and where learners use new forms of communication in on-line conversations and need to use accommodation and mediation strategies in order to negotiate the meaning of their messages.

Let's now look at some of those innovative notions and relevant research fields that are emerging in these moveable scenarios and explore how teachers may inform their English language lessons, either by extending their course-books with new tasks and activities or by devising complementary classroom-based teaching materials. Notions as authenticity, English as a Lingua Franca, cultural and intercultural competence, tools as ICTs and corpora, approaches such as content and language integrated learning (CLIL), the development of aspects of pragmatics (CRANDALL\&BASTURKMEN, 2004) of communicative and mediation strategies are unavoidable features of the English language classrooms and are de facto beginning to inform English course-books and all types of teaching materials. In the following sections, some of the traditional teaching tools and innovative approaches will be briefly presented within a new perspective and possible 
ways of extending their use within the language classrooms as teaching materials, will be illustrated.

\subsection{COURSE-BOOKS}

Based upon theoretical and practical pedagogical perspectives, course-books, as well as supporting teaching materials, are the most powerful tools in guiding teachers' work and sustaining learners' development, because they are chosen by teachers themselves, the only ones who know about and are capable to respond to their classroom needs; but a course-book does not always meet the variety of conditions present in a language classroom (UR,1996; RICHARDS, 1993, 2014; RICHARDS \& MAHONEY, 1996). Sometimes, teachers need to explore teaching materials outside course-books and modify them in order to be relevant to the needs and the demands of particular groups of students. Course-books, whether global or local, are still perceived by both teachers and learners as the primary source for language learning, they save teachers' preparation time, provide a carefully structured teaching and learning path and are reliable resources, as it is often the case with the grammar book, that is still there next to teachers and learners, mainly with a reassuring function.

Among the questions to be used when analyzing and evaluating course-books, the following are examples used within a language teacher education course adopting a reflective WE/ELF-informed approach held at Roma Tre University, Italy (LOPRIORE \& VETTOREL, 2015):

- Do current course-books offer an innovative approach with a view to the multiplicity of English language varieties and variations, as well as to the growing numbers of multilingual learners? Do course-book take into account the need to develop learners' cultural and intercultural awareness and competences?

Through these questions teachers were elicited to reflect on WE\&ELF relevance for language learners, on the current plurilingual school population as well as on the need to develop learners' intercultural awareness.

- Do course-books accompanying materials provide teachers with multiple authentic resources and with communicative tasks focused on strategic and mediation interactions? Are samples of authentic spoken language provided as part of spoken language development? Is the traditional list of language functions enriched with examples of negotiation and accommodation? Are aspects of pragmatics part of the spoken language component?

These four questions are meant to elicit teachers' attention to the use of authentic resources and to the main features of spoken interaction.

- How much and how is content and language integrated in the syllabus?

This was particularly meant to focus teachers' awareness of ways content is presented through language. 
- What contexts and which characters are used to represent English speaking cultures?

In all WE/ELF informed teacher courses, the first step to have teachers reflect upon course-books is by focusing on how English speaking cultures are represented.

Even if in course-book presentations publishers highlight their 'global' orientation and the presence of English-speaking characters from diverse cultural and linguistic backgrounds, course-books are still very much based on an EFL view and on nativespeaker models, and this is clearly traceable in the audio recordings and visible in the type of activities that are being promoted (VETTOREL \& LOPRIORE, 2013; TAKAHASHI, 2014; CALEFFI, 2016). Very seldom, for example, course-book audio and video materials offer recordings of varieties of English by native and non-native English speakers. Listening activities in course-books rarely ask learners to focus on features of authentic conversations, to notice differences and similarities in pronunciation or to respond to a variety of audio inputs. Listening development is very often limited to discrete item understanding. Spoken language is seldom explicitly taught and communicative, accommodation and mediation strategies are rarely included in the course syllabus nor their use enhanced in the tasks provided (CALEFFI, 2016).

\section{Implications for teaching materials}

Course-books, even if they do not offer room for teachers' individual teaching paths, can still offer a springboard for teachers, since they can daily rely on them and, at the same time, further develop their contents by resorting to and adapting authentic materials, such as on-line resources, by devising appropriate tasks, or by engaging learners in noticing activities, for example, in oral interactions by using, for instance, excerpts from TV series. Audio and video materials currently available on the web are excellent resources for teachers who wish to integrate their lesson plans and their course-books, and in many cases they have already been transformed to teaching aids by the same producers, as in the case of TED materials, for example.

\subsection{GRAMMAR BOOKS}

In spite of several changes occurred in language teaching approaches and in the type of materials considered useful for language learning, the way classroom grammar books have developed in time, has brought very little changes in their construct as well as in their organization. This is mostly due to authors' and users' inner beliefs about what language is and how it should be represented so, even if course-books have brought about numerous and important innovations, a much slower change has occurred in the way grammar books are conceived and developed. Grammar, this uncountable noun referring to a system of rules, has always been looked at as something separate from the communicative process, to be learnt by means of a grammar, a countable noun referred to those books where grammar rules are contained and explained (LARSEN-FREEMAN, $2000,2001)$. But grammar can be perceived - and learnt - also as a dynamic process, as something that one does in order to understand language whereby learners themselves 
'grammar', a verb, i.e. make sense of language. In a time of change where language in use is the starting point for sustaining language awareness, the traditional format of grammar books can be exploited if language awareness activities are complemented by language in use activities.

This view of grammar as a process was introduced by Diane Larsen-Freeman (2000, 2001) who challenged both the traditional association of 'grammar' with the idea of 'rules' and the arbitrariness of rules. Learners, according to Larsen-Freeman (2000), should constantly be encouraged to understand the reasons underlying rules since reasons are broader-based than rules: they explain 'more phenomena than single syntactic structures'. 'The way to address the problem is to change the way teachers think about grammar [...] grammar is a dynamic system' (LARSEN FREEMAN in PEREZ-LLANTADA , 2007: p.158). Larsen-Freeman (2000) provides clear guidelines on how to sustain teachers in overcoming barriers set by traditional grammar presentations as well as learners in their reasoning about language.

Implications for teaching materials

Within this reflective approach teachers can make the reasons behind rules 'transparent', students will be able to use the reasons and the rules rather than learning the rules by heart. Learners will be able to see the logic of the language and they will acquire a lifelong skill that will empower them. In this type of approach to grammar, teachers play a fundamental role since they can develop specific language tasks and prepare sets of teaching materials with samples of authentic language use, by asking learners to 'reason' about language and to 'notice' language use, encouraging them to draw their own conclusions about 'how' a structure is formed, 'what' it means and 'when and why' it is used. Teachers' produced materials can be developed within this type of approach, accompanying traditional grammar teaching and complementing the use of grammar books.

\subsection{AUTHENTICITY}

The notion of authenticity has been explored and discussed in diverse contexts and on different occasions over the last forty years (BREEN, 1985, 1987; DAY, 2003; WIDDOWSON, 1978, 1990; GILMORE, 2007; WATERS, 2009), mostly in terms of the type of constructed vs. authentic language samples as used in course-books, and it is now once more brought under the magnifying glass of recent research on English as a Lingua Franca, an area that challenges the very nature of authenticity and highlights the relevance of social context and the notion of localized language use (PREISLER, 2014; PINNER, 2016).

Michael Breen (1985) had originally made a distinction between four types of authenticity: the one of input texts, that of learners' interpretation of those texts, that of learning tasks, and the one of classroom social context (BREEN, 1985: 61). He had though, according to Widdowson, "generalized the meaning of authenticity" by assuming that whatever takes place in the classroom is authentic (WIDDOWSON, 1990: 46). In 
terms of pedagogical principles, Breen's distinction rightly underlines that there are different senses of the word authenticity, while Widdowson sustains that no materials are authentic in their own right, rather they need to be authenticated by those using them (WIDDOWSON, 1978), i.e. by the learners and by their teachers. More and more there is the need to focus on local contexts, trusting teachers' experience and developing appropriate localized materials and course-books for specific language groups (GILMORE, 2007). Teachers, particularly non-native ones, can thus encourage learners to 'practise' authenticity by engaging them both in the use of authentic materials, but also by engaging them in tasks whereby resorting to communicative strategies they 'authenticate' their language use (PREISLER, 2014).

\section{Implications for teaching materials}

This emerging notion of authenticity thus provides a new role and a different function to local teachers who would become the 'local and legitimate authors' in classroom-based curriculum and teaching materials development. Local teachers would thus be the only ones capable of identifying classroom needs, look for local materials, respond to learners' needs and find appropriate resources; they would engage learners in 'authentic' exchanges through meaningful and 'authentic' tasks, whereby learners would be put in the position of resorting to all their language resources, of using their communicative strategies, as well as of identifying samples of authentic language as used outside the classroom. This type of approach would thus empower learners as confident language users and would encourage teachers to work in teams, to identify and use a variety of out-of-classroom authentic resources, and to develop materials accompanying traditional teaching materials as course-books or grammar books, thus highlighting diverse instantiations of English language and building strong local teacher communities.

\subsection{CORPORA}

In the last two decades studies of language have been more and more represented by studies of language use, of how the language used by speakers and writers is used in naturally occurring texts. The analysis of language use goes beyond traditional grammar description and investigates the reasons why language has so many structures similar in meaning and grammatical function. There are many factors to be taken into consideration in this respect as, for example, the recurrent patterns in language exchanges, the features of the language used by different authors, the varieties of the language we daily choose to adopt, and the different registers used in conversation, in newspapers or in radio news.

In order to find out more about typical patterns of language use, the extent to which patterns are found or the factors that influence variability, we cannot just rely on intuition and we should refer to a large amount of language. A corpus is a large and principled collection of natural texts or utterances considered more or less representative of a language that, mainly stored as an electronic database, is used for purposes of general linguistic analysis. The corpus based approach has provided a way to investigate language use without wasting too much time, thus enhancing the development of more and more 
research work while providing a new perspective to the teaching of foreign languages. Corpus Linguistics is a method in linguistics which involves the computerized retrieval, and subsequent analysis, of linguistic elements and structures from corpora (LOPRIORE, 2012, 50).

The use of Corpus Linguistics has introduced a different way of exploring language in current foreign language publications as well as in language research studies in ESP, in discourse analysis or in media studies (SINCLAIR, 1991; BIBER, CONRAD, REPPEN, 1998). In the last few years foreign language teachers have frequently encountered this term associated to different fields and areas even if they haven't yet started to use it themselves or to fully understand its contribution to language studies. Corpus studies are now being used more often to inform the production of teaching materials so that the more common choices of usage are given more attention than those which are less common (LOPRIORE, 2012, 52). This type of corpus-based approach to material development is gradually leading to a reflective change in teachers' view of the language while enhancing learners' personal response (SINCLAIR, 2004; O'KEEFE, McCARTHY, CARTER, 2007; REPPEN, 2010). Corpus examples expose students to the kinds of sentences that they will encounter when using the language in real life situations. Language corpora have recently become a resource for the language learning and teaching processes, because corpora may unveil information about the way language works and may prove a powerful tool for developing learners' language awareness. There is a growing number of corpora of standard English and of its varieties, besides the British National Corpus, the American Brown Corpus, the spoken corpus of MICASE, the Cambridge Corpus etc., there are also corpora of English Lingua Franca, such as the VOICE Corpus, the ELFA Corpus and the ACE.

\section{Implications for teaching materials}

Corpora can sustain teaching material development, course-book writing and lesson planning, because they offer teachers the opportunity to base their work on naturallyoccurring language, thus avoiding the use of purpose-made examples. Teachers can use corpora to investigate language in use (idioms, collocations, lexical phrases or grammar patterns), identify uses of a language (register, genres, ESP) or understand how spoken language works. Using specific software, teachers - as well as students - can produce lists of frequencies, discover patterns in natural language that would not otherwise be visible, and analyze how language systematically clusters into combinations of words or chunks (McCARTHY, 2006; LOPRIORE, 2009, 2012; REPPEN 2010).

The existence of numerous corpora of standard varieties as well as of varieties and variations of English, offers yet another opportunity for learners to notice different instantiations of language in use and to teachers to use them for developing teaching materials (McCARTHY, 2006; O'KEEFE, McCARTHY, CARTER, 2007; LOPRIORE, 2009, 2012; REPPEN, 2010). Most corpora are currently available on-line and some websites, as the one provided by Mark Davies at Brigham University, where different corpora are available for consultation, can facilitate classroom-based activities locally led by teachers and represent yet another and innovative teaching materials 
Teachers, by resorting to corpora or by developing their own corpus, may more easily match what they teach about the language with samples of language in use and show authentic examples taken from spoken or written language corpora; teachers can thus become researchers into their own practice and provide more learning-centred, consciousness-raising activities. Resorting to corpora may prove useful for language learners since, by observing language in use, they are empowered, they formulate hypotheses about the language in a text and they check their hypotheses in the corpora, they start acting as 'language detectives' thus becoming more autonomous learners.

\subsection{COMMUNICATION \& MEDIATION STRATEGIES}

Language learners have linguistic constraints and face communication problems and breakdowns more often than first language users. The new multilingual landscapes where most English language learners and teachers work, demand for skills to facilitate communication as well as for specific practice tasks aimed at sustaining learners' development of effective communicative skills. This is particularly true when breakdowns occur in communication and must be overcome when interacting with other non-native speakers in a multicultural environment, as it is the case of most schools nowadays. This is achieved mainly through a conscious use of strategies of different types, all regarded as powerful learning tools that should be embedded in the language learning process.

But, what are 'strategies'? And how can they become part of the teaching-learning process? Communication strategies are: "potentially intentional attempts to cope with any language-related problems of which the speaker is aware during the course of communication", (DÖRNYEI \&SCOTT, 1997, p. 179) and they should be sustained and enhanced by teachers with authentic tasks and materials.

The vast existing literature on language strategies, starting from the seventies, has included studies on learning strategies, "devices a learner may use to acquire knowledge" (RUBIN, 1975 , p. 43) that have been greatly influential on ELT pedagogy (STERN, 1975; RUBIN, 1975, 1987; TARONE, 1980; OXFORD, 1990; O'MALLEY et al, 1985), on communicative strategies "devices for compensating for inadequate resources" (ELLIS, 1986, p.165), perceived as useful tools for language learners who wish to communicate (STERN, 1975; ELLIS, 1986; CANALE \& SWAIN, 1980). The distinction made between grammatical, discourse, sociolinguistic and strategic competences (CANALE \& SWAIN, 1980; O'MALLEY \& CHAMO'T, 1990), as well as the contributions of O'Malley et al, (1985) who added and highlighted the social dimension, and Savignon \& Sysoyev's enlightening article on sociocultural strategies (SAVIGNON \& SYSOYEV, 2002), have stretched the notion of communicative strategies beyond the language classroom walls situating them within learners' social context.

Most recently, particularly in the last two decades when language borders are 'leaking' and repertoires are very much dependent upon local communities, studies on pragmatics and on multilingualism have unveiled the way young people communicate in their own social contexts and within social media, and how they resort to translanguaging 
practices, practices that "take us beyond the ugly and simplistic labels of grammartranslation versus communicative language teaching that have reduced English to a language used and taught only in its own presence" (PENNYCOOK, 2008, 30.7).

Some of these studies (CANAGARAJAH, 2013, 2014; GARCIA \& LI WEI, 2014; PENNYCOOK, 2008) have emphasized the role of new forms of communication through English, taking place in different sociolinguistic environments, where younger multicultural generations use different types of cross-cultural communication as well as accommodation and mediation strategies in their interactions, where code-switching is now replaced by code-mixing and code-meshing.

Very recently the Common European Framework (CEFR) descriptors for language mediation have been developed and analyzed. Mediation is the fourth communicative language activity presented in CEFR, complementing reception, interaction and production (NORTH, 2016, 131), as the CEFR described its function:

In both the receptive and productive modes, the written and/or oral activities of mediation make communication possible between persons who are unable, for whatever reason to communicate with each other directly. Translation or interpretation, a paraphrase, summary or record, provides for a third party a (re)formulation of a source text to which this third party does not have direct access. Mediation language activities, (re)processing an existing text, occupy an important place in the normal linguistic functioning of our societies." (COUNCIL OF EUROPE 2001, p.14)

The CEFR description clearly hints at the relevance of this activity for learners' development in multilingual and multicultural contexts. As Brian North points out:

A fundamental point about mediation is that it is not concerned with the linguistic expression of a speaker. Instead, the focus is on the role of language in processes like creating the space and conditions for communication and/or learning, constructing new meaning, encouraging others to construct or understand new meaning, passing on information in an appropriate form, and simplifying, elaborating, illustrating or otherwise adapting input in order to facilitate these processes (mediation strategies). Mediation always involves bridging across spaces, facilitating understanding. (NORTH, 2016, p. 133)

As a consequence, the use and development of mediation strategies have become a useful reference for teachers as well as for learners, and mediators become intermediaries between different interlocutors; this underlines the social and collaborative vision of language

Implications for teaching materials

The emerging language landscapes and the multicultural contexts demand

"[...]a reconceptualization of the role of teachers of languages. Teachers enact the teaching of particular languages in their local context as members of distinctive multilingual and multicultural communities. They bring their own particular repertoires of languages, cultures, and histories of experiences that shape their frameworks of knowledge, understandings, values, and practices. It is these frameworks of interpretive resources that they use in mediating language learning with students who, in turn, use their own interpretive resources" (SCARINO, 2014, p.386). 
Angela Scarino (2014) points at how teachers in their localized contexts can revisit their own teaching and value learners' lives and languages; she highlights the very nature of teachers' new role and function, that of mediating language learning with their students. How can this turn into teaching materials created by teachers? One of the immediate investments can be based upon classroom based tasks for the development of learners' awareness of communicative, learning and mediating strategies use in authentic or semiauthentic projects and tasks. Teachers may start by developing specific conversation tasks based upon classroom project work where learners are asked to observe and take notes of the type of strategies used to:

- $\quad$ express a concept they could not find the corresponding word in English;

- intervene in group discussions when making decisions about the project;

- explain what to do when someone in the team did not understand;

- negotiate meaning in discussions;

- etc.

They could then be asked to write their own strategy list with all the types of strategies that they have used or they noticed their mates used. This way teachers can plan a 'strategy use' set of materials whereby learners gradually realise whether they are resorting to their mother tongue or just creating new words, and how they use language - whether English, their L1, their local dialects, translanguaging, code meshing etc. - to facilitate meaning making. These activities could be associated with course-book materials on spoken language development and linked to watching excerpts of TV series where learners are asked to observe how language is used by characters to accommodate or to mediate with the interlocutors.

\subsection{CULTURAL AND INTERCULTURAL COMPETENCE}

Among the emerging issues in the new scenarios of English language teaching one is the notion of intercultural communication, in terms of both teaching and learning and of the competences learners from different cultural backgrounds might need and are expected to develop (BYRAM, 2008; CORBETT, 2010; COUNCIL of EUROPE, 2001; HOLLIDAY, HYDE, KULLMAN, 2004). And this is particularly true in contexts where English is more and more being used as a lingua franca.

"A key component of intercultural communicative competence is the ability to mediate between people in conflict, whose misunderstanding might well arise from differences in cultural perspectives." (CORBETT, 2010, p.9)

Teachers of English all over the word are forced to revisit the content and the ways of delivery of their teaching, in order to equip their learners in different exchanges, including cross-cultural interactions. Too often failure of comprehension is attributed to faulty language competence, while - within an intercultural approach - learners may be sustained in identifying and value differences. Most of the literature on cultural and 
intercultural communication has underlined what the Council of Europe had highlighted in 2001, that is:

In an intercultural approach, it is a central objective of language learning to promote the favourable development of the learner's whole personality and sense of identity in response to the enriching experience of otherness in language and culture. (COUNCIL OF EUROPE, 2001, p. 1)

Since there is not only one route to achieving successful intercultural communication, it is important for teachers to devise teaching materials most suitable to the local contexts where they teach. Intercultural communication is one of those areas where there have been several theoretical publications, and few, but extremely rich, activity books providing suggestions at all levels, but it is one of those notions seldom included in course-books. Intercultural communication is a cross-curricular area since it is closely connected to the development of language awareness, of language functions, of all language skills, of grammar, and of lexis. Course-books usually provide readings on different cultures in a stereotyped way, disregarding implications for strengthening learners' communicative skills. Choosing to focus on learners' identities and on their ability to interact in multicultural environments is fundamental, since, "Intercultural learners use language to explore different cultures, and to mediate in those situations where cultural misconceptions occur" (CORBET'T, 2010, p.2).

\section{Implications for teaching materials}

As mentioned before, there are few, but very interesting books on intercultural language activities (CORBETT, 2010; HOLLIDAY et al., 2004), usually based upon categories such as identity, food, sport, politics, religion, conflict mediation, conflict resolutions, public spaces, domestic life, films, etc. .

The structure of these activities includes an outline, a focus, and a procedure where learners are usually involved mainly in spoken interaction tasks. Most materials are available on the web, where learners can be asked to identify authentic samples of different cultures and identities. If a school platform is available to the students, they can use the platform for reinforcing their research of features of different cultures, but also, to sustain as well as use multicultural exchanges in international projects, as in the case of e'Twinning or of TANDEM projects. These types of projects may trigger the development of teaching materials that would integrate course-books and could be sustained by setting up discussion groups where learners are involved in identifying intercultural skills.

\section{CONCLUSIONS}

Teaching English as a globalized language in multicultural contexts requires appropriate materials that are being mostly developed by publishers all over the world, but course-book analyses have shown that course-books still disregard current developments of English, as in the case of English as a Lingua Franca, of new aural and 
oral resources, of new forms of communication, of multiculturalism and multilingualism, of language education, of the role of non-natives, and of tools such as corpora. Even if there have never been so many supporting books in the ELT industry, still teachers are alone in their local contexts where things are changing more deeply and profoundly than in the global dimension, and where the context demands for sustaining learners' identity development.

Suggestions provided in this contribution aim at encouraging teachers to stretch the borders of their classroom walls and of their course-books, by becoming themselves authors in the local place.

Teachers should be empowered to develop supporting materials, they are the ones who can localize them, by identifying appropriate resources and adapting them to the local learners' needs, thus empowering their learners as well.

"The effectiveness of classroom materials ultimately depends on how they are used by teacher and learners, and how that use enables learners to become competent in the language, however competence is defined" (GARTON \& GRAVES, 2014: 273)

\section{REFERENCES}

BIBER, D., CONRAD, S., REPPEN, R., Corpus Linguistics, Cambridge: Cambridge University Press, 1998.

BREEN, M. The social context for language learning: a neglected situation. Studies in Second Language Acquisition, 1, 1985, p.135-158.

BREEN, M. Authenticity in the language classroom. Applied Linguistics, v.6, n.1, 1987.

BYRAM, M. From Foreign Language Education to Education for Intercultural Citizenship. Essays and reflections. Clevedon: Multilingual Matters, 2008.

CALEFFI, P. ELF in the Speaking and Listening Activities of Recently Published English-language Course-books. In LOPRIORE, L \& GRAZZI, E. (Eds.) Intercultural Communication. New Perspectives from ELF. Roma: Roma Tre Press, 2016, p.59-76.

CANDLIN, C. \& BREEN, M. Evaluating, adapting and innovating language teaching materials. In: YORIO, C.; PERKINS, K.; SCHACTER, J. (Eds.). On TESOL '79: The learner in focus. Washington, DC: TESOL, 1979.p. 86-108.

CANALE, M. \& SWAIN, M. Theoretical bases of communicative approaches to second language teaching and testing, Applied Linguistics, 1, 1980, p.1-47.

CANAGARAJAH, A. S. Translingualpractice. New York/Abingdon, UK: Routledge, 2013.

CANAGARAJAH, A. S. Theorizing a competence for translingual practice at the contact zone. In: May, S. (ed.) The multilingual turn: Implications for SLA, TESOL and bilingual education. New York/ Abingdon, UK: Routledge, 2014, p. 78-102. 
COLEMAN, H. (Ed.). Dreams and Realities: Developing Countries and the English Language. London: The British Council, 2011.

COOK, V. Materials for adult beginners from an L2 user perspective. In TOMLINSON, B. (Ed.), Developing materials for language teaching. London, UK: Continuum, 2003. p. 275290.

CORBET'T, J. Intercultural Language Activities. Cambridge: Cambridge University Press, 2010.

COUNCIL OF EUROPE Common European Framework of Reference for Languages: Learning, Teaching, Assessment. Cambridge Cambridge University Press, 2001.

CRANDALL, E. \& BASTURKMEN, H. Evaluating pragmatics-focused materials. ELT Journal, v.58, 2004. p.38-49.

DAY, R. Authenticity in the design and development of materials. In RENANDYA, W. A. (Ed.), Methodology and materials design in language teaching: Current perceptions and practices and their implications. Singapore: SEAMEO Regional Language Centre, 2003. p. 170-191.

DÖRNYEI Z.\& SCOTT, M. L. Communication Strategies in a Second Language: Definitions and Taxonomies. Language Learning, 47. p. 173-210, 1997.

ELLIS, R. Understanding second language acquisition. Oxford: Oxford University Press, 1986.

GARCIA, O., WEI, L. Translanguaging: Language, bilingualism and education. Basingstoke, UK: Palgrave Macmillan, 2014.

GARTON S., GRAVES K. (Eds) International Perspectives on Materials in ELT. International Perspectives on English Language Teaching. London: Palgrave Macmillan, 2014.

GILMORE, A. Authentic materials and authenticity in foreign language learning. Language Teaching, 40, 2007, p.97-118.

GRADDOL, D. English Next, London: The British Council, 2006.

HOLLIDAY, A., HYDE, M., KULLMAN, J. Intercultural Communication: An Advanced Resource Book. London: Routledge, 2004.

HOWATT, A. P. R. \& SMITH, R. The History of Teaching English as a Foreign Language, from a British and European Perspective. Language and history, v. 57 n. 1, 2014. p. 75-95.

KNAPP, K. English as an International Lingua Franca and the Teaching of Intercultural Communication. Journal of English as a Lingua Franca v.4, n.1, 2015. p.173-189.

LARSEN FREEMAN, D. Grammar: Rules and reasons working together. ESL Magazine, January/February 2000, p. 10-12.

LARSEN FREEMAN, D. Teaching Languages: from Grammar to Grammaring, Heinle \& 
Heinle, 2001.

LITTLEJOHN, A. The analysis of language teaching materials: inside the Trojan Horse. In: TOMLINSON, B. (Ed.) Materials development in language teaching ( ${ }^{\text {nd }}$ ed.). Cambridge: Cambridge University Press, 2011. p.179-211.

LIT'TLEJOHN, A. \& WINDEATT, S. Beyond language learning: Perspective on materials design. In: R. K. Johnson (Ed.), The second language curriculum. Cambridge: Cambridge University Press, 1989. p.155-175.

LOPRIORE L. Corpora in the Language Classroom. SPELT QUARTERLY, v. 24 n.4, p. 10-16, 2009.

LOPRIORE, L. Buqzwords in ELT. Unveiling English. Rome: Anicia, 2012.

LOPRIORE, L. \& VETTOREL, P. Promoting awareness of Englishes and ELF in the English language classroom. In: H. Bowles and A. Cogo (Eds), International Perspectives on English as a Lingua Franca. Pedagogical Insights (pp. 13-34). Basingtoke: Palgrave Macmillan, 2015.

McCARTHY, M. Explorations in Corpus Linguistics. Cambridge: Cambridge University Press, 2006.

NORTH, B. Developing CEFR illustrative descriptors of aspects of mediation. International Online Journal of Education and Teaching (IOJET), v.3 n. 2, 2016, p.132-140.

O'KEEFE, A., McCARTHY, M., CARTER, R. From Corpus to Classroom. Cambridge: Cambridge University Press, 2007.

O’MALLEY, J. M., UHL CHAMOT, A., STEWNER-MANZANARES, G., RUSSO, R., KUPPER, L. Learning strategy applications with students of English as a second language, TESOL Quarterly, 1985, v. 19 n.3, p.557-584.

O'MALLEY, J. M., UHL CHAMOT, A., Learning strategies in second language acquisition. Cambridge: Cambridge University Press, 1990.

OXFORD, R. Language Learning Strategies: What every teacher should know. NY: Newbury House, 1990.

PENNYCOOK, A. Translingual English. Australian review of applied linguistics, v.31, 30.130.9, 2008.

PÉREZ-LLANTADA, C. New Trends in Grammar Teaching: Issues and Applications: An Interview with Prof. Diane Larsen-Freeman. Atlantis, v.29, n. 1 2007, p.157-163.

PINNER, R.S. Reconceptualising Authenticity for English as a Global Language, Multilingual Matters, 2016.

PREISLER, B. Lecturing in one's first language or in English as a lingua franca: The communication of authenticity. Acta Linguistica Hafniensia , v. 46 , n. 2, 2014. 
REPPEN, R. Using Corpora in the Language Classroom. Cambridge: Cambridge University Press, 2010.

RICHARDS, J. C. Beyond the textbook: the role of commercial materials in language teaching. RELC Journal, v.24, 1993. p. 1-14.

RICHARDS J.C. The ELT Textbook. In: GARTON, S. \& GRAVES, K. (eds) International Perspectives on Materials in ELT. London: Palgrave Macmillan, 2014. p.1936.

RICHARDS, J. \& MAHONEY, D. Teachers and textbooks: A survey of beliefs and practices. Perspectives, v.8, n.1, 1996. p. 40-63.

RUBIN, J. What the 'good language learner' can teach us. TESOL Quarterly, 9, 1975, p.41-51.

RUBIN, J. Learner strategies: theoretical assumptions, research history and typology. In Wenden, A. \& Rubin, J. (Eds), 1987, p.15-19.

SAVIGNON, S.J., \& SYSOYEV, P.V. Sociocultural strategies for a dialogue of cultures. The Modern Language Journal, v.86, n.4, 2002, p.508-524.

SCARINO, A. Learning as Reciprocal, Interpretive Meaning-Making: A View From Collaborative Research Into the Professional Learning of Teachers of Languages. The Modern Language Journal, v. 98: 386-401, 2014.

SHARIFIAN, F. (Ed.) English as an International Language. Bristol: Multilingual Matters, 2009.

SHELDON, L. E. (Ed.). ELT textbooks and materials: Problems in evaluation and development. ELT Documents 126. London, UK: Modern English Publications and the British Council, 1987.

SINCLAIR, J. Corpus, Concordance, Collocation, Oxford: Oxford University Press, 1991.

SINCLAIR, J., How to Use Corpora in Language Teaching, John Benjamins, 2004.

STERN, H. H. What can we learn from the good language learner? Canadian Modern Language Review, 34, 1975, p. 304-318.

TAKAHASHI, R. An analysis of ELF-oriented features in ELT course-books: Are attitudes towards non-native varieties changing in English language teaching policy and practice in Japan? English Today, v.30 n.1, 2014, p.28-34.

TARONE, E. Communication strategies, foreigner talk, and repair in interlanguage. Language Learning, v.30 n.2, 1980, p. 417-429.

TOMLINSON, B. (Ed.) Materials Development in Language Teaching. Cambridge: Cambridge University Press, 2003.

TOMLINSON, B. Principles for effective materials development. In Harwood, N. (Ed) 
English language teaching materials: theory and practice, Cambridge, Cambridge University Press, 2010.

TOMLINSON, B. (Ed.) Materials development in language teaching (2 ${ }^{\text {nd }}$ ed.). Cambridge: Cambridge University Press, 2011.

TOMLINSON, B. (2012). Materials development for language learning and teaching. Language Teaching v.45, n.2, 2012. p.143-179.

TOMLINSON, B. (Ed.) Applied linguistics and materials development. New York, NY: Bloomsbury, 2013.

TOMLINSON, B., \& MASUHARA, H. Research in materials development: Evidence for good practice. London, UK: Continuum, 2010.

UR, P. A Course in Language Teaching. Practice and Theory. Cambridge: Cambridge University Press, 1996.

VETTOREL, P. \& LOPRIORE, L. Is there ELF in ELT course-books? Studies in Second Language Learning and Teaching, v.3, n.4, 2013,483-504.

WATERS, A. Ideology in Applied Linguistics for Language Teaching. Applied Linguistics, v.30, n.1,2009.

WIDDOWSON, H. Learning language as communication. Oxford: Oxford University Press, 1978.

WIDDOWSON, H. Aspects of Language Teaching. Oxford: Oxford University Press, 1990.

\section{WEBSITES}

\begin{tabular}{|l|l|}
\hline $\begin{array}{l}\text { BRIGHAM YOUNG } \\
\text { UNIVERSITY }\end{array}$ & https://corpus.byu.edu_Last access 29.11.2017 \\
\hline VOICE CORPUS, WIEN & https://www.univie.ac.at/voice/ Last access 03.01.2018 \\
\hline $\begin{array}{l}\text { ELFA CORPUS, } \\
\text { HELSINKI }\end{array}$ & $\begin{array}{l}\text { http://www.helsinki.fi/englanti/elfa/elfacorpus } \\
\text { Last access 28.11.2017 }\end{array}$ \\
\hline $\begin{array}{l}\text { ASIAN CORPUS, HONG } \\
\text { KONG }\end{array}$ & http://corpus.ied.edu.hk/ace/_Last access 03.01.2018 \\
\hline E-TWINNING & https://www.etwinning.net/it/ Last access 03.01.2018 \\
\hline TANDEM & https://tandem.net Last access 03.01.2018 \\
\hline
\end{tabular}

Recebido em: 01/08/2017

Aprovado em: 15/11/2017

Publicado em: 30/12/2017 